\title{
The Rationale for Industrial and Innovation Policy
}

\author{
Mario Cimoli \\ University of Venice \\ Giovanni Dosi \\ Scuola Superiore Sant'Anna, Pisa \\ Joseph Stiglitz \\ Columbia University
}

\begin{abstract}
The evolution of industries in the last two centuries in all countries has been closely supported by a wide range of public policies addressing the patterns of capital accumulation, trade rules, the organisation of markets, innovative efforts and the process of knowledge creation and diffusion. Specific institutions have been created supporting such developments and have played a key role in economic growth. The protection of infant industries, the definition of trade and intellectual property regimes, the distribution of rents and the coherence with macroeconomic policies are key elements of such policies. The current challenges of industrial and innovation policies are discusses in the light of recent experiences in emerging countries.

Keywords: secondary sector, public policy, industrial policy, market/commercial policy, industrialization, international trade, intellectual property, macroeconomics
\end{abstract}




\section{The evolution of industries ${ }^{1}$}

A fundamental element in countries that successfully caught-up with the leaders during the 19th and 20th centuries was active government support of the catch-up process, involving various forms of protection and direct and indirect subsidy. The guiding policy argument has been the need of domestic industry in the industries of the day judged critical in the development process for some protection from advanced firms in the leading nations. Alexander Hamilton's argument (1791) for infant industry protection in the new United States was virtually identical to that put forth decades later by Friederich List (1841) regarding Germany's needs. Gershenkron's (1962) famous essay documents the policies and new institutions used in Continental Europe to enable catch-up with Britain. The same story also fits well with the case of Japan, and of Korea and Taiwan somewhat later. In many countries these policies engendered not successful catch-up but a protected inefficient home industry. However, they also were the hallmark during the 20th century of all the countries that have achieved their goals of catching-up. ${ }^{2}$ We need to learn more about the circumstances under which infant industry protection leads to a strong indigenous industry: the project on which this work draws shed new light on the issue.

These policies obviously angered companies in the leading countries, and their governments, particularly if the supported industry not only supplied its home market but began to invade the world market. While the case made after World War II for free trade was mostly concerned with eliminating protection and subsidy among the rich countries, and at that time there was sympathy for the argument that some infant industry protection was often useful in developing countries, the more recent international treaties that have been made increasingly have been used against import protection and subsidy in countries seeking to catch-up from far behind.

Our belief is that Hamilton and List were and continue to be right that successful catch-up in industries where international trade is considerable requires some kind of infant industry protection or other modes of support.

Table 1. summarizes an exploratory taxonomy of policy interventions, measures and related institutions.

In the last resort, policies and other activities of "institutional engineering" affect together (i) the technological capabilities of individual and corporate organizations,

\footnotetext{
${ }^{1}$ This paper draws upon M. Cimoli, G. Dosi and J. E. Stiglitz (eds.), The Political Economy of Capabilities Accumulation: the Past and Future of Policies for Industrial Development, Oxford University Press (2009) and on successive joint work by the authors. The research leading to this work has enjoyed the long-term backing of the Initiative for Policy dialogue (IPD), Columbia University.

${ }^{2}$ For a broad historical overview of the role of policies in some now-developed countries, see Reinert (2004).
} 
and the rate at which they actually learn; (ii) the economic signals that they face (including of course profitability signals and perceived opportunity costs); (iii) the ways they interact with each other and with non-market institutions (e.g. public agencies, development banks, training and research entities, etc.)

It happens that all major developed countries present indeed relatively high degrees of intervention - whether consciously conceived as industrial policies or not - that affect all the above variables. And this applies, even more so, to the period when today's developed countries were catching-up with the international leader. What primarily differentiate the various countries are the instruments, the institutional arrangements and the philosophy of intervention.

The case of of Japan is a paradigmatic example of catching-up policies (DosI, 1984).

Interestingly, Japan appears to have acted comprehensively upon all the variables categorized in our taxonomy above. A heavy discretionary intervention upon the structure of signals (also involving formal and informal protection against imports and foreign investments) recreated the "vacuum environment" that is generally enjoyed only by the technological leader(s). However, this was matched by a pattern of fierce oligopolistic rivalry between Japanese companies and a heavy export orientation which fostered technological dynamism and prevented any exploitation of protection simply in terms of collusive monopolistic pricing.

It is tempting to measure this Japanese experience - notwithstanding, recent, mostly macroeconomic difficulties - with others, on average less successful, such as the European ones, which heavily relied upon one single instrument, financial transfers (especially R\&D subsidies and transfers on capital account), leaving to the endogenous working of the international market both the determination of the patterns of signals and the response capabilities of individual firms. Certainly, there are country-specific features of the Japanese example which are hardly transferable. However, that case, in its striking outcome, points at a general possibility of reshaping the patterns of "comparative advantages" as they emerge from the endogenous evolution of national and international industries.

Table 1. Processes and institutions for policies on technological learning and industrial change

\begin{tabular}{l|l|l}
\hline $\begin{array}{l}\text { Domains of policy } \\
\text { intervention }\end{array}$ & Policy measures & Related institutions \\
\hline $\begin{array}{l}\text { (i) Opportunities } \\
\text { of scientific and } \\
\text { technological } \\
\text { innovation }\end{array}$ & $\begin{array}{l}\text { Science policies, graduate } \\
\text { education, "frontier" } \\
\text { technological projects }\end{array}$ & $\begin{array}{l}\text { Research universities, } \\
\text { public research centers, } \\
\text { medical institutes, space } \\
\text { and military agencies, etc. }\end{array}$ \\
\hline
\end{tabular}




\begin{tabular}{|c|c|c|}
\hline $\begin{array}{l}\text { Domains of policy } \\
\text { intervention }\end{array}$ & Policy measures & Related institutions \\
\hline $\begin{array}{l}\text { (ii) Socially } \\
\text { distributed learning } \\
\text { and technological } \\
\text { capabilities }\end{array}$ & $\begin{array}{l}\text { Broader education and } \\
\text { training policies }\end{array}$ & $\begin{array}{l}\text { From primary education to } \\
\text { polytechnics, to US-type } \\
\text { "land-grant colleges", etc. }\end{array}$ \\
\hline $\begin{array}{l}\text { (iii) Targeted Industrial } \\
\text { Support Measures, } \\
\text { affecting e.g. types } \\
\text { of firms, etc. - in } \\
\text { primis the structure, } \\
\text { ownership, modes } \\
\text { of governance of } \\
\text { business firms (e.g. } \\
\text { domestic vs. foreign, } \\
\text { family vs. publicly } \\
\text { owned companies, } \\
\text { etc.) }\end{array}$ & $\begin{array}{l}\text { From the formation } \\
\text { of state-owned firms } \\
\text { to their privatization, } \\
\text { from "national } \\
\text { champions" policies to } \\
\text { policies affecting MNCs } \\
\text { investments; all the } \\
\text { way to the legislation } \\
\text { affecting corporate } \\
\text { governance }\end{array}$ & $\begin{array}{l}\text { State-owned holdings, } \\
\text { public merchant banks, } \\
\text { public "venture capitalist", } \\
\text { public utilities }\end{array}$ \\
\hline $\begin{array}{l}\text { (iv) The capabilities } \\
\text { of economic } \\
\text { agents (in the first } \\
\text { instance business } \\
\text { firms) in terms of } \\
\text { the technological } \\
\text { knowledge they } \\
\text { embody, the } \\
\text { effectiveness and } \\
\text { speed with which } \\
\text { they search for } \\
\text { new technological } \\
\text { and organizational } \\
\text { advances, etc. }\end{array}$ & $\begin{array}{l}\text { cf. especially points } \\
\text { (ii), (iii) and also R\&D } \\
\text { policies; policies affecting } \\
\text { the adoption of new } \\
\text { equipment, etc. }\end{array}$ & \\
\hline $\begin{array}{l}\text { (v) The economic } \\
\text { signals and incentives } \\
\text { profit-motivated } \\
\text { agents face (including } \\
\text { actual and expected } \\
\text { prices and profit } \\
\text { rates, appropriability } \\
\text { conditions for } \\
\text { innovations, entry } \\
\text { barriers, etc.) }\end{array}$ & $\begin{array}{l}\text { Price regulations; } \\
\text { tariffs and quotas in } \\
\text { international trade; } \\
\text { Intellectual Property } \\
\text { Rights regimes, etc. }\end{array}$ & $\begin{array}{l}\text { Related regulatory } \\
\text { agencies, agencies } \\
\text { governing research and } \\
\text { production subsidies, } \\
\text { trade controlling entities, } \\
\text { agencies granting and } \\
\text { controlling IPRs }\end{array}$ \\
\hline
\end{tabular}




\begin{tabular}{|c|c|c|}
\hline $\begin{array}{l}\text { Domains of policy } \\
\text { intervention }\end{array}$ & Policy measures & Related institutions \\
\hline $\begin{array}{l}\text { (vi) Selection } \\
\text { mechanisms } \\
\text { (overlapping with the } \\
\text { above) }\end{array}$ & $\begin{array}{l}\text { Policies and legislation } \\
\text { affecting Anti-trust and } \\
\text { competition; entry and } \\
\text { bankruptcy; allocation } \\
\text { of finance; markets for } \\
\text { corporate ownership; etc. }\end{array}$ & $\begin{array}{l}\text { Anti-trust authorities, } \\
\text { institutions governing } \\
\text { bankruptcy procedures, } \\
\text { etc. }\end{array}$ \\
\hline $\begin{array}{l}\text { (vii) Patterns of } \\
\text { distribution of } \\
\text { information and } \\
\text { of interaction } \\
\text { amongst different } \\
\text { types of agents (e.g. } \\
\text { customers, suppliers, } \\
\text { banks, shareholders, } \\
\text { managers, workers, } \\
\text { etc.) }\end{array}$ & $\begin{array}{l}\text { Governance of labor } \\
\text { markets, product } \\
\text { markets, bank-industry } \\
\text { relationships, etc. all the } \\
\text { way to collectively shared } \\
\text { arrangements for within- } \\
\text { firms information-sharing } \\
\text { mobility and control, } \\
\text { forms of cooperation and } \\
\text { competition amongst } \\
\text { rival firms, etc. (cf. for } \\
\text { example the historical } \\
\text { differences between } \\
\text { Japanese vs. Anglo-Saxon } \\
\text { firms) }\end{array}$ & \\
\hline
\end{tabular}

Certainly, the historical experience shows a great variety of country and sectorspecific combinations between the types of policies illustrated above. Some subtle regularities nonetheless emerge.

First, a regularity, holding from 19th century Europe and US all the way to contemporary times, is the centrality of public agencies, such as universities, and public policies in the generation and establishment of new technological paradigms. ${ }^{3}$

Second, and relatedly, "incentives are often not enough". A crucial role of policies is to affect the capabilities of the actors, especially in the foregoing case of new technological paradigms, but also in all cases of catching-up whereby no reasonable incentive structure might be sufficient to motivate private actors to surmount big technological lags.

Third, market discipline is helpful in so far as it weeds out the low performers and rewards the high performers within particular populations of firms. However, nothing guarantees that too high selective shocks will not wipe out the entire populations themselves, thus also eliminating any future learning possibility.

Fourth, policies - especially those aimed at catching-up - generally face the need to balance measures aimed at capability building (and also at protecting the "infant learner") with mechanisms curbing inertia and rent-seeking. For example, the latter

3 In particular on the serendipitous impact of public mission oriented programs after WWII see Mazzucato (2013). 
are indeed one of the major elements missing in the old Latin American experience of import substitution while the former are what is lacking under many more recent "liberalization" policies.

Fifth, historically, a successful catching-up effort in terms of per capita income and wages has always been accompanied by catching-up in the new and most dynamic technological paradigms, irrespective of the initial patterns of comparative advantages, specialization and market-generated signals. Our conjecture is that, ceteris paribus, the structural need for policies affecting also the patterns of economic signals (including relative prices and relative profitabilities) as they emerge from the international market will be greater, the higher the distance of any one country from the technological frontier. This is what Amsden (1989) has provocatively called policies of deliberately "getting the prices wrong". Conversely, endogenous market mechanisms tend to behave in a "virtuous" manner for those countries that happen to be on the frontier, especially in the newest/most promising technologies. This is broadly confirmed by historical experience: unconditional free trade often happened to be advocated and fully exploited only by the technologically and politically leading countries.

The lessons from the past are useful in so far as they apply also to the future. Today, policy making ought to be acutely aware of the fact that future capabilities build upon, refine and modify incumbent ones: hence the policy goal of building good path-dependencies (see also HAUSMANN and RODRICK, 2006). Below is a list of feasible policies that go in this direction.

\section{The necessity of nurturing infant industries}

Safeguarding the possibility of learning, is indeed the first basic pillar of the infant industry logic.

On the incentive side, market signals left to themselves are often not enough and indeed frequently discourage the accumulation of technological capabilities in so far as they ought to occur in activities currently displaying significant comparative disadvantages and thus also unfavourable current profitabilities. Incidentally note, also, that the existence of financial markets are meagre instruments, if at all, for translating a future and uncertain potential for learning into current investment decisions (more in StIGLITZ, 1994; and STIGLITZ and GREENWALD, 2014). Thus, there are sound learning-related reasons why historical evidence shows that, just prior to industrial catching-up, average industrial import tariffs are relatively low; they rise rapidly in the catching-up phase, and they fall after a mature industrialization. Indeed, it is during the catching-up phase that the requirement of distorting (international) market signals is more acute, precisely because there are young and still relatively fragile learning infants. Partly it has to do with the fact that many forms of protection entail the possibility of learning but not, in the language of Khan 
and Blankenburg (2009), the 'compulsion' to innovate as distinct from the sheer incentive to just exploit a monopoly rent, no matter how inefficient and lazy is the potential 'learner' (more on this below). Partly, it has to do with the conditions of capabilities accumulation and the characteristics of the actors involved.

After all, even under the best intentions and incentives, industrialization might have rather little to do with the sheer award of property rights and with the establishment of firms as legal entities (cf. HobdaY and PERINI, 2009). Of course, the legal context does matter and is likely to be a conducive condition. However, this is far from sufficient. In fact, it is quite misleading to think that all over the world there are plenty of sources of technological knowledge just awaiting to be exploited - the lag being due mainly to institutional and incentive-related forces. In fact, irrespectively of the opportunities for the entrepreneurial exploitation of technological knowledge which the 'international knowledge frontier' notionally offer, the fundamental gap regards precisely the lack of capabilities in exploring and exploiting them. 'horizontal ' policies of education and training, together with the activities of technical support to firms by public institutions can go a long way in the capability-enhancing direction. But even that is not likely to be enough. In fact policies are often bound to get their hands explicitly dirty with respect to the nature, internal structure, strategies of few corporate agents themselves.

Fostering the emergence and in a few occasions explicitly building technologically and organizationally competent firms are indeed fundamental infant nurturing tasks.

Needless to say the absence/existence of mature technological capabilities and 'dynamic capabilities' for changing them (cf. TEECE, PISANO, and SCHUEN,1997) in any one country is not a binary variable. However, the distribution is highly uneven. So, one could list several dozen countries which can hardly show any. Other countries do display some technologically progressive organizations in a bigger sea of less dynamic firms. In fact, even the most developed countries present only a fraction of technologically dynamic organizations within a much greater population of firms. (Note that all this applies to both 'high tech' and 'low tech sectors as conventionally defined). In a sense, industrialization has to do with the properties of changing distributions between 'progressive' and 'backward' firms. How do policies affect such dynamic? Dahlman, (2009) reports on China and India, but the historical lesson goes well beyond these two country cases. Policies happened to involve

(i) state ownership;

(ii) selective credit allocation;

(iii) favourable tax treatment to selective industries;

(iv) restrictions on foreign investment;

(v) local context requirements;

(vi) special IPR regimes; 
(vii) government procurement;

(viii) promotion of large domestic firms.

In a nutshell, this is the full list of the capital sins which the market faithful are supposed to avoid!

There is here again a widespread misunderstanding to be dispelled, which goes under the heading of 'picking-the-winner' or 'national champion' fallacies. Why should governments foster national oligopolists or monopolists in the first place? And how could governments be more 'competent' than market in selecting who is technologically better or worse?

There certainly are unintentional or even counter-intentional outcomes of discretionary industrial policies. Of course, untainted pro-market advocates typically quote among OECD countries the failures of the computer support programmes and the Concord project in Europe as archetypes of such 'government failures' to be put down on the table against 'market failures'. Economists more sympathetic to the positive role of the public visible hand, including us, would find easy to offer the cases of Airbus or ST Microelectronics in Europe, Petrobras and Embraer in Brazil, etc., among many others, as good counterexamples. However, our point goes well beyond this. The 'picking the winner idea' basically builds on the unwarranted myth that there are many 'competitors out there' in the market, and the government has the arrogance of 'knowing better' than the market in their selection. This is often far away from reality in developed countries and, even more so, in catchingup ones. And in fact it happens that the major vehicles of learning and catching-up in all episodes of successful industrialization, with the possible exception of little Singapore, have been domestic firms - sometimes alone, sometimes in joint-venture with foreign MNCs -, but rarely MNCs themselves. This holds from German and American industrialization all the way to current China - possibly the case nearest to a two-pronged strategy, both fostering the development of domestic firms and trying to squeeze out of foreign MNCs as much technological knowledge as possible.

Historically, the 'infant learners' had to be shielded or helped in the domestic and international markets essentially in their interactions with the more efficient and more innovative firms from 'frontier' countries. In these interactions, there is no reason to give up the 'infant nurturing' philosophy. On the contrary, it adds to the reasons urging to push toward a more explicit use of the domestic or regional markets as venues of culture of an emerging national industry even when the latter tends to be squeezed on the international arena between 'advanced productions' and Chinese exports. ${ }^{4}$

\footnotetext{
${ }^{4}$ China quickly reduces its absolute disadvantages across the board, in both more traditional productions and in activities based on the newest technological paradigms. And it does so at rates higher than its catchingup in wages (notwithstanding the fast growth of the latter). The outcome is an absolute cost advantage in an expanding set of goods including those which were/are central to industrial production of many low and middle income countries.
} 


\section{Infant industries under the new international Trade Regime}

There is another big novelty in the current organization of international economic relations, namely the regulatory regime stemming from the World Trade Organization (WTO) and the TRIPS agreements (more on them below). The latter ones have implied stronger constraints on what is admissible in terms of subsidies and other discretionary forms of support to firms and industries.

What can be done?

Quite a few things can be done also within the incumbent agreements, full as they are of loopholes and of provisions for exceptions generally put there by the negotiators of developed countries with an eye on their special interests - ranging from dubiously defined 'anti-dumping measures' to national safety and security considerations. Developed countries (in fact, frequently, the very representatives of special industrial interests in person, mostly from the U.S., EU and Japan), have been quick in exploiting these provisions. Developing countries have rarely done so, overwhelmed by the power of the money, the political clout, the lawyers' sophistication, the power of blackmail by stronger States. At least equally common has been so far the unawareness of these opportunities for pragmatic management, certainly thickened - we caricature on purpose - by Chicago-trained ministers of the economy truly believing that all problems come from the fact that trade liberalization has not gone far enough, and directors-general of the ministry of trade who had been taught that the Heckscher-Ohlin-Samuelson theorem on gainsfrom-trade is the last word on the subject. There are other things that must be avoided at all costs: among them, shy away from 'bilateral' agreements.

In brief, 'bilateral' agreements are WTO-plus, and, in terms of Intellectual Property Rights, 'TRIPS-plus' agreements, whose bottom line is to close the loopholes/exceptions/safeguard clauses of the original WTO and TRIPS agreements, freezing them in favour of the companies and industries from the developed world. So, a bilateral agreement, most often with the U.S., offers 'preferred country clauses', typically concerning textile exports and the like, which we know do not matter much, if at all, since Chinese exports are more competitive even if one takes away all tariff on the developing country's export. On the other more subtle side, the provisions of the bilateral agreement often involve the unconditional acceptance of the IPR regime imposed by the developed partner and curbs on imports from third countries of commodities produced under the various waivers still contemplated under the WTO. While there are significant and still largely unexploited degrees of freedom unintentionally provided by the current international trade institutions and rules, the straight jacket is likely to remain too tight. As Dahlman (2009) remarks, if China and India "had liberalized 
from the beginning it is unlikely that they would be the strong economic powers that they have become. To a large extent, some of the strengths of both countries are that they developed strong capabilities before they liberalized". The point applies of course also to the countries which are beginning now their process of capability accumulation. But then the conclusion is that some trade renegotiation is going to be necessary. It is reasonable for example to switch to a regime whereby the object of multilateral agreement are average industrial tariffs as distinct from tariffs that are line-by-line or apply to specific products and sectors.

The system is simpler than the current structure of tariff commitments and would also reconcile multilateral discipline with policy flexibility since countries would be able subject to an overall average ceiling while maintaining degrees of freedom for discretionary sectoral strategies. In practice it would have the effect of balancing tariff increases and reductions, since a country would need to lower its practised tariffs on some products in order to be able to raise them on others. This would encourage governments to view tariffs as temporary instruments and focus the efforts to ensure that they effectively serve the purpose they are designed for, that is to provide a breathing space for infant industries before they mature and catch up with their counterparts in more advanced countries.

Moreover, within such a logic, the average ceiling itself ought to depend on the levels of technological and economic development, raising as the catching up process is put in motion and falling as industrialization become ripe.

\section{A management of the distribution of rents favourable to learning and} industrialization

The other side of 'infant nurturing' policies discussed above regards the rent distribution profile that they entail. We have already emphasized that offering an opportunity of learning via, say, a temporary trade barrier, does not imply per se the incentive to do so rather simply exploiting the rents stemming from the protection. As outlined by Khan and Blankenburg (2009), successful industrialization policies have all come with rent management strategies providing for compulsions for learning and accumulation of both technological capabilities and production capacity. There are three sides to such strategies.

First, on the 'carrot' side, policies must be able to transfer resources to the 'progressive actors' : fiscal policies, subsidies, preferential credits, grants are among the possible means. In fact, fiscal policies are particularly important in the transfer of resources from those activities which benefit from (cyclical or, even 
more so, trend) improvements in the terms of trade of natural resources - in the form of export levies, royalties indexed on the final price of the commodities, fines and taxes discouraging environmental damage. Moreover, the construction of industrialization-friendly financial institutions is of paramount importance . Second, on the 'stick' side, governments must have the credibility to commit to developmental rents for periods that are sufficiently long but not too long (of course how long will depend on the sectors; the nature of the technologies; the distance from the international frontier; the initial capabilities of managers, technicians, workers, etc.). In that, of course, the critical requirement is the credible commitment to stop all rent-yielding measures after some time and, in any case, to withdraw them and impose sanctions on firms and industries failing to achieve technological investment or export targets. Third, the nurturing of domestic oligopolists has to be matched by measures fostering competition. There is a general lesson coming from the experiences of Korea, and some decades before Japan, whereby quasi-monopolistic or oligopolistic domestic firms were forced, quite early on, to compete fiercely on the international markets. And, together, above some threshold of industrial development, antitrust policies are an important deterrent against the lazy exploitation of 'infant protection'.

Indeed, the management of rent distribution in its relation with industrial learning is one of the most difficult and most crucial tasks of any industrialization strategy, as it concerns the overall distribution of income, wealth and political power across economic and social groups.

4. Tight Intellectual Property Rights regimes never help industrialization and sometimes harm it

All catching-up countries - including, to repeat, at one time also the United States and Germany - have done so through a lot of imitation, reverse engineering, straightforward copying. But these activities are precisely what strong property right protection is meant to prevent. How effective IPR are in achieving this objective depends a lot on the technologies and the sectors but certainly when they are effective they are likely to represent an obstacle to domestic technological learning. Conversely, if IPR protection may represent an incentive to innovate in frontier countries - a claim indeed quite controversial, not supported by particularly robust evidence (cf. again Dosı et al., 2006, for a discussion) -, there is no evidence that they have any positive effect in spurring innovative activities in catching-up countries. Certainly, successful industrializers at some point start innovating and also patenting, but typically - a century ago as well as today - 
they fill their patent claim in frontier countries where their strongest competitors are likely to be based. At the same time, the domestic IPR regime has been characteristically weak. The situation, however, has recently changed with TRIPS agreements which have basically extended the tightest IPRs rules of developed countries to all the signing countries, including developing ones, and has been made even worse by the already mentioned bilateral agreements. Further, TRIPS has taken away the possibility of differentiation the regime of protection across products and technologies.

First, it is to be aware and never buy the story that 'IPR are good for development because they are good for innovation'. On the contrary, in many technological areas they are largely irrelevant for both innovation and technological catchingup. In other areas like, in primis, drugs, they are definitely harmful for imitation and capability building in catching-up countries (while they have indeed a dubious effect on the rates of innovation in frontier countries). A consequence of such an awareness is also the need of greater efforts to build institutional capabilities and a clear 'technology acquisition strategy' to orient negotiations and dispute settlements.

Second, and relatedly, TRIPS agreements contain a series of loopholes, safeguard clauses and exceptional provisions - for example concerning compulsory licensing which catching-up countries have still to learn how to exploit.

Third, the most advanced among catching-up countries ought to strive to offer relatively less developed ones appealing regional agreements which could be viable alternatives to the bilateral agreements with the U.S. (and the EU) generally containing IPR provisions even stricter than TRIPS.

Last but not least, also in this case, alike in the trade of goods -already discussed - a new wave of multilateral negotiations are likely to be needed aimed at

(i) reducing the breadth and width of IPR coverage;

(ii) expanding the domain of unpatentability - from scientific knowledge to algorithms to data -, and,

(iii) conditioning the degrees of IPR protection on the relative level of economic and technological development of each country.

After all, the current international IPR regime is largely the response to the special appropriability interest of a small sub-set of developed countries' firms - basically Big Pharma and biotech, Microsoft and Hollywood. A reform in the directions just indicated would benefit catching-up countries, but also the first-world consumers, without doing any harm to the overall rate of innovation. 


\section{The necessary consistency between macroeconomic and industrial policies}

As extensively discussed in several chapters of Cimoli, Dosi and Stiglitz (2009) addressing the Latin American experience over the last two decades, there are macroeconomic policies which kill most learning efforts together with most forms carrying the related learning capabilities. Sudden and indiscriminate dismantling of trade barriers can easily do that, especially if it comes together with reckless (non) management of exchange rates, characterized by vicious cycles of appreciation followed by sudden devaluations. And the cycles have been only amplified by the stubborn refusal to utilize controls over capital movements, especially shortterm movements. Blind trust in the 'magic of the market place' and the associated lack of fiscal policies and demand management increases output volatility. In turn, the latter, together with the endemic financial fragility of many developing countries' firms means induced waves of corporate mortality and with that also the disappearance of the capabilities of technological accumulation. And even among surviving firms, behaviours tend to become more short-term and the economy tends to respond more to financial signals than to long term learning opportunities (more on all that in OCAMPO and TAYLOR, 1998; and STIGLITZ et al., 2006). The comparative tales of Latin American countries as compared to e.g. Korea or Malaysia, tell the importance of the vicious feedbacks between macro policy shocks prescribed by orthodox recipes and micro dynamics (in Latin America) vs. the virtuous feedbacks between more interventionist and 'Keynesian' macro policies and the continuing industrial expansion even under severe financial crises (e.g. in Korea).

\section{References}

Amsden A., (1989), Asia Next Giant, Cornell University Press

M. CIMoLI, G. Dosi and J. E. Stiglitz (eds.), (2009) The Political Economy of Capabilities Accumulation: the Past and Future of Policies for Industrial Development, Oxford University Press

DAHLMAN C.J. (2009). 'Growth and Development in china and India: The Role of Industrial Innovation Policy in Rapid Catch-Up', in Cimoli M., G. Dosi, J.E. Stiglitz, 2009 Dosı G., (1984), Technical Change and Industrial Transformation, London, Macmillan and New York, St. Martin Press

Dosi, G. Marengo, L., and PAsquali, C. (2006). 'How much should society fuel the greed of innovators? On the Relations Between Appropriability, Opportunities and Rates of Innovation', Research Policy, 35-8: 1110-1121

Gerschenkron A., (1962),. Economic Backwardness in Historical Perspective, Harvard University Press, Cambridge 
Hamilton A., (1791), "Report on the Subject of Manufactures", in Syrett H.C. et al. (1966), The Papers of Alexander Hamilton, vol. X, Columbia University Press, New York HAusmanN, R., and RodRIK, D. (2006). 'Doomed to Choose: Industrial Policy as Predicament'. CID Working Paper. Center for International Development at Harvard University.

Hobday M., and F. Perini (2009). 'Latecomer Entrepreneurship: A Policy Perspective' in CIMolı M., G. DosI, J.E. STIGLITZ, 2009

Khan M. H., and S. Blankenburg (2009). 'The Political Economy of Industrial Policy in Asia and Latin America', in Cimoli M., G. Dosi, J.E. Stiglitz, 2009

LIST F., (1841), The National System of Political Economy, trans. S.S. Lloyd, London: Longmans, Green and Co.; first published in English translation, 1885

Mazzucato, M. (2013), The Entrepreneurial State: Debunking Public vs, Private Sector Myths, Anthem Press

OCAMPO, J. A. and Taylor, L. (1998), 'Trade liberalization in developing economies: modest benefits but problems with productivity growth, macro prices, and income distribution', The Economic Journal, 108, 1523-1546

ReINERT E.S., (2004), "How Rich Nations got Rich. Essays in the History of Economic Policy", Working paper Nr. 1, SUM - Centre for Development and the Environment, University of Oslo (3 articles)

StIglitz J., (1994), Whither Socialism?, Cambridge, Mass.: The MIT Press

Stiglitz, J.E., , Ocampo, J.A., Spiegel S., Ffrench-davis, R., and Nayyar, D. (2006). Stability with Growth. Macroeconomics, liberalization and development. New York/ Oxford: Oxford University Press.

Stiglitz J.E. and B.C. Greenwald (2014). Creating a Learning Society: A New Approach to Growth, Development, and Social Progress, (Kenneth J. Arrow Lecture Series), Columbia University Press, N.Y.

Teece, D., Pisano, G., and Shuen, A. (1997). 'Dynamic Capabilities and Strategic Management'. Strategic Management Journal, 18-7: 509-533.

Mario Cimoli

Director of the Division of Production, Productivity and Management at the United Nations' Economic Commission for Latin America and the Caribbean (ECLAC) and Professor of Economics at the University of Venice (Ca' Foscari). Contact: mario.cimoli@cepal.org

Giovanni Dosi

Professor of Economics and Director of the Institute of Economics at the Scuola Superiore Sant'Anna in Pisa; CoDirector of the task forces "Industrial Policy" and "Intellectual Property Rights", IPD - Initiative for Policy Dialogue at Columbia University; Continental European Editor of Industrial and Corporate Change. Contact: gdosi@sssup.it

Joseph Eugene Stiglitz

Professor at Columbia Business School, the Graduate School of Arts and Sciences (Department of Economics) and the School of International and Public AffairsUniversity. Contact: jes322@columbia.edu 